\title{
PENINGKATAN TITIK LEMBEK ASPAL TERMODIFIKASI MENGGUNAKAN BLOCK SKIM RUBBER (BSR) TERDEPOLIMERISASI
}

\author{
Melting Point Enhancement of Modified Asphalt Using \\ Depolymerized Block Skim Rubber \\ Arief RAMADHAN dan Norma Arisanti KINASIH \\ Pusat Penelitian Karet \\ Jalan Salak No. 1 Bogor 16151 \\ Email: arif@puslitkaret.co.id; norma.kinasih88@gmail.com
}

Diterima : 25 Januari 2015 / Direvisi : 22 April 2015 / Disetujui : 2 Juli 2015

\begin{abstract}
Asphalt pavement has lower melting point than pavement surface temperature. A pavement is damaged particularry at high ambient temperature. Melting point enhancement of the asphalt can be done by an addition of natural rubber in asphalt. The addition of sulphur and resin need to be given on natural rubber-modified asphalt for increasing the compatibility of natural rubber-asphalt. The purpose of this research was to analyze the characteristic of modified asphalt, which made from an addition of depolymerized block skim rubber (BSR), sulphur and resin. Asphalt modifier such as depolymerized BSR was added as much as 6\% (w/w), whereas sulphur and resin were added as much as 2, 4, and $6 \%(w / w)$ for each. The best formulation of asphalt modifier was selected based on the highest melting point of modified asphalt. The characterization of modified asphalt, which made from depolymerized BSR and sulphur has higher melting point and slower mixing time than modified asphalt, which made from depolymerized $B S R$ and resin. The best formulation was resulted from an addition of $6 \%$ $(w / w)$ depolymerized BSR and 6\% (w/w) sulphur, which reach $75^{\circ} \mathrm{C}$ melting point. This value has meet a minimum value of melting point polymer asphalt, which was $56^{\circ} \mathrm{C}$ in asphalt polymer standard (SNI 6749:2008).
\end{abstract}

Keywords: Asphalt, melting point, depolymerized block skim rubber, sulphur, resin

\begin{abstract}
Abstrak
Titik lembek jalan beraspal cenderung lebih rendah dibandingkan dengan suhu di permukaan jalan. Terutama pada suhu lingkungan yang tinggi, jalan beraspal menjadi rusak. Peningkatan titik lembek aspal dapat dilakukan dengan penambahan karet alam pada aspal. Penambahan belerang dan resin perlu diberikan pada aspal termodifikasi karet alam untuk meningkatkan kompatibilitas aspal-karet alam. Penelitian ini bertujuan untuk
\end{abstract}

menganalisis karakteristik aspal termodifikasi yang dihasilkan dari penambahan karet alam jenis block skim rubber (BSR) terdepolimerisasi, belerang, dan resin terhadap titik lembek aspal termodifikasi. Bahan pemodifikasi aspal seperti BSR terdepolimerisasi ditambahkan sebanyak $6 \%(\mathrm{~b} / \mathrm{b})$, sedangkan belerang dan resin masingmasing ditambahkan sebanyak 2, 4, dan $6 \%$ (b/b). Formulasi terbaik bahan pemodifikasi dipilih berdasarkan titik lembek tertinggi yang dihasilkan. Karakteristik aspal termodifikasi BSR terdepolimerisasi dan belerang menghasilkan titik lembek aspal yang lebih tinggi dan waktu pencampuran yang lebih lambat dibandingkan dengan aspal termodifikasi BSR terdepolimerisasi dan resin. Formulasi aspal termodifikasi terbaik dihasilkan dari penambahan $6 \%$ (b/b) BSR terdepolimerisasi dan $6 \%(\mathrm{~b} / \mathrm{b})$ belerang, dengan nilai titik lembek yang dicapai sebesar $75^{\circ} \mathrm{C}$. Nilai ini memenuhi standar minimum titik lembek aspal yang dipersyaratkan oleh standar aspal polimer (SNI 6749:2008) sebesar $56^{\circ} \mathrm{C}$.

Kata kunci: Aspal, titik lembek, block skim rubber, terdepolimerisasi, belerang, resin

\section{PENDAHULUAN}

Kerusakan dini pada jalan beraspal di Indonesia sering dijumpai akibat tingginya beban lalu lintas kendaraan dan suhu di permukaan jalan. Pada siang hari suhu di permukaan jalan dapat mencapai $\pm 50^{\circ} \mathrm{C}$, suhu ini lebih tinggi daripada titik lembek aspal, yaitu sebesar $\pm 48^{\circ} \mathrm{C}$ (Cifriadi et al., 2012). Hal ini menyebabkan material aspal menjadi lunak, sehingga tampak retakan pada permukaan jalan beraspal.

Peningkatan titik lembek aspal dapat dilakukan dengan menambahkan polimer sebagai bahan aditif aspal. Beberapa hasil penelitian menunjukkan bahwa 
penambahan polimer (baik karet alam maupun sintetik) pada aspal dapat meningkatkan titik lembek aspal (Tuntiworawit et al., 2005; Nrachai et al., 2005; Xiang et al., 2009; Kök dan Çolak, 2011 ; Prastanto, 2014 ). Namun, pencampuran karet alam dengan aspal membutuhkan waktu yang lama sehingga menjadi kendala dalam pemrosesannya.

Panjangnya rantai polimer di karet alam menyebabkan proses pencampuran dengan aspal memerlukan waktu yang lama. Sehingga diperlukan proses pemendekkan rantai polimer karet melalui depolimerisasi. Menurut Prastanto (2014), penambahan karet alam (SIR 20) terdepolimerisasi pada aspal dapat mempersingkat waktu pencampuran dibandingkan dengan penambahan SIR 20 tanpa perlakuan depolimerisasi.

Kompatibilitas karet dan aspal dapat ditingkatkan dengan penambahan bahan aditif seperti; senyawa berbasis fosfor (Giafirani et al., 1996; Zhang dan Yu, 2009), aditif berbasis belerang (Sun et al., 2006; Chen dan Huang, 2007) dan maleat anhidrat (Becker et al., 2003; Polacco et al., 2005). Hasil penelitian Chen dan Huang (2007) menunjukkan bahwa penambahan persentase belerang pada aspal termodifikasi polimer (SBS) dapat meningkatkan titik lembek aspal dan menurunkan penetrasi aspal.

Selain itu, kompatibilitas aspal dan polimer dapat pula ditingkatkan dengan penambahan resin. Becker et al (2001) menerangkan bahwa pada aspal yang ditambahkan polimer dalam jumlah yang kecil, peningkatan konsistensi dan sifat elastisitas pengikat dilakukan dengan penambahan resin dan asphalten. Aspal berdasarkan sifat dispersinya disusun oleh asphalten dan malten. Secara umum malten tersusun dari sistem koloid resin, lilin, senyawa alifatik dan aromatik (Browarzik et al., 1999; Murgich et al., 1996). Maka resin merupakan bagian dari aspal itu sendiri.

Pada penelitian ini akan dikaji pengaruh penambahan karet alam jenis BSR terdepolimerisasi, belerang dan resin terhadap perbaikan sifat aspal. Komposisi bahan aditif aspal terbaik dinilai berdasarkan tingginya titik lembek aspal yang dicapai serta kecepatan waktu pencampuran bahan tersebut di aspal. Titik lembek aspal termodifikasi terbaik diharapkan memenuhi standar titik lembek aspal polimer yang dipersyaratkan SNI 6749:2008.

\section{BAHAN DAN METODE}

Penelitian dilaksanakan di laboratorium penelitian dan pabrik percobaan Pusat Penelitian Karet pada Februari hingga Desember 2010. Bahanbahan yang digunakan untuk pembuatan aspal modifikasi antara lain; BSR, aspal minyak (penetrasi 60), belerang, dan resin jenis coumarone resin. Sedangkan bahanbahan yang dibutuhkan untuk analisa antara lain; kertas sigaret (TST), gliserin dan air suling. Alat-alat yang dibutuhkan untuk membuat aspal modifikasi; open mill, pengaduk (rotor), pemanas, timbangan dan gelas piala. Sedangkan alat yang dibutuhkan untuk analisa antara lain; Mooney viscometer, plastimeter Wallace, ring holder dan ball centering guide. Penelitian ini meliputi dua kegiatan yaitu:

\section{Depolimerisasi BSR dan Analisa BSR Terdepolimerisasi}

Proses depolimerisasi dilakukan secara mekanik melalui pelunakan ( mastikasi) dingin $\left(\mathrm{suhu}<60^{\circ} \mathrm{C}\right)$ menggunakan open mill. Penggilingan dilakukan secara bertahap, pada tahap awal mastikasi dilakukan selama 5 menit, kemudian dilanjutkan selama 24 menit. Analisis parameter mutu BSR terdepolimerisasi dilakukan sebelum dan setelah proses depolimerisasi dilakukan. Parameter mutu yang diuji antara lain; plastisitas awal (Po), indeks ketahanan plastisitas (PRI) dan viskositas Mooney.

\section{Pembuatan dan Analisis Aspal Modifikasi}

Pembuatan aspal modifikasi dilakukan dengan mencampurkan aspal dengan BSR terdepolimerisasi, belerang dan resin. Aspal yang digunakan sebanyak 300 g. Sedangkan bahan pemodifikasi seperti BSR terdepolimerisasi ditambahkan sebanyak 6\% (b/b), sedangkan belerang dan resin masing-masing ditambahkan sebanyak 2, 4, dan 6\% (b/b) pada aspal. 
Untuk memudahkan pencampuran, BSR terdepolimerisasi dipotong-potong tipis terlebih dahulu.

Mekanisme pencampuran aspal dan BSR terdepolimerisasi dengan belerang dan resin dilakukan secara terpisah, namun mekanisme pencampuran keduanya dilakukan secara sama. Tahapan pencampuran aspal dengan bahan pemodifikasi diawali dengan mencairkan aspal menggunakan kompor listrik pada suhu $160^{\circ} \mathrm{C}$ dan dihomogenkan menggunakan rotor $(20 \mathrm{rpm})$. Waktu penghomogenan aspal tanpa bahan pemodifikasi kemudian dicatat sebagai acuan pembanding waktu penghomogenan aspal termodifikasi.

Setelah aspal cair homogen, ditambahkan 2 , 4 , dan $6 \%(\mathrm{~b} / \mathrm{b})$ belerang. Setelah belerang tercampur homogen (visual), 6\% (b/b) BSR terdepolimerisasi ditambahkan. Waktu pencampuran aspal dengan bahan pemodifikasi dicatat sebagai waktu homogen aspal termodifikasi.

Proses pencampuran kemudian dilakukan kembali untuk mencampurkan aspal dan BSR terdepolimerisasi dengan resin. Aspal termodifikasi yang diperoleh kemudian didinginkan dan diuji sifat titik lembek sesuai SNI 6749:2008. Komposisi terbaik aspal termodifikasi dipilih berdasarkan tingginya titik lembek yang dihasilkan.

\section{Analisis Statistik}

Data percobaan kemudian diolah secara statistik menggunakan rancangan acak lengkap faktorial dengan dua kali ulangan menggunakan software SPSS (Statistical Package for the Social Sciences). Model matematik rancangan percobaan yang digunakan adalah sebagai berikut:

$$
\mathrm{Y}_{\mathrm{ijk}}=\mu+\mathrm{A}_{\mathrm{i}}+\mathrm{B}_{\mathrm{j}}+\mathrm{AB}_{(\mathrm{ij})}+\varepsilon_{(\mathrm{ijk})}
$$

Keterangan:

$\mathrm{Y}_{\mathrm{ij \textrm {k }}} \quad$ = Variabel respon yang diukur

$\mu \quad=$ Nilai tengah populasi

$\mathrm{A}_{\mathrm{i}} \quad=$ Pengaruh faktor $\mathrm{A}$ pada taraf ke-i

$B_{j} \quad=$ Pengaruh faktor A pada taraf ke- $\mathrm{j}$

$\mathrm{AB}_{(\mathrm{ij})}=$ Pengaruh interaksi dari faktor $\mathrm{A}$ taraf ke-i dengan faktor $B$ taraf ke-j

$\varepsilon_{(i \mathrm{jk})}=$ Pengaruh galat dari unit percobaan ke-k dalam kombinasi perlakuan uji

\section{HASIL DAN PEMBAHASAN}

\section{Karakteristik BSR Terdepolimerisasi}

Viskositas yang tinggi dari karet alam akan mempersulit pencampurannya dengan aspal. Hal ini dikarenakan bobot molekul yang tinggi dari karet menunjukkan ikatan rantai molekul yang panjang (derajat polimerisasi tinggi) sehingga memerlukan energi (panas) yang cukup besar dan waktu yang lama untuk dapat memutus ikatan antar rantai molekul karet dalam proses pencampurannya dengan aspal. Maka perlu dilakukan proses depolimerisasi agar bobot molekul karet menurun, sehingga energi dan waktu yang digunakan lebih efisien.

Depolimerisasi adalah penguraian polimer menjadi monomer secara bertahap (Cowd, 1991). Depolimerisasi BSR dilakukan secara mekanik melalui pelunakan (mastikasi) dingin. Adanya tenaga mekanis yang dihasilkan dari gaya geser antara permukaan gilingan dengan karet blok mengakibatkan pemutusan rantai molekul karet. Pemutusan rantai molekul akan menghasilkan radikal-radikal bebas yang akan mengikat oksigen dari udara, sehingga terbentuk molekul-molekul yang stabil. Pada proses mastikasi karet alam akan terjadi penurunan berat molekul dari orde $10^{6}$ hingga menjadi sepuluh kali lebih rendah (Kartowardojo, 1980). Penurunan berat molekul karet tampak pada nilai viskositas Mooney BSR terdepolimerisasi (Tabel 1) yang menurun hingga 14,4.

Plastisitas awal (Po) adalah ukuran plastisitas karet yang secara tidak langsung memperkirakan panjangnya rantai polimer molekul atau bobot molekul karet. Maka nilai ini sebanding dengan nilai viskositas Mooney nya. Secara visual BSR terdepolimerisasi memiliki bentuk yang lebih lunak dibandingkan BSR. Sedangkan nilai PRI menunjukkan ketahanan karet terhadap oksidasi panas. Nilai ini berbanding terbalik dengan nilai viskositas Mooney. Pengukuran viskositas Mooney sama dengan pengukuran tenaga gesekan antara rotor dengan karet sebagai tahanannya (Refrizon, 2003). Maka semakin plastis karet, maka semakin cepat rotor berputar, sehingga semakin kecil tenaga yang dibutuhkan untuk memutar rotor. Tabel 1 menunjukkan bahwa nilai PRI pada BSR dan BSR terdepolimerisasi berbanding 
terbalik dengan nilai viskositas Mooneynya. Nilai PRI BSR lebih kecil dibandingkan BSR terdepolimerisasi.

\section{Karakteristik Aspal Termodifikasi BSR Terdepolimerisasi dan Belerang}

Pencampuran antara aspal, BSR terdepolimerisasi dan belerang secara visual menunjukkan reaktifitas yang tinggi. Reaktifitas interaksi antar bahan diminimalisir dengan cara memasukkan potongan BSR terdepolimerisasi secara perlahan dan dilakukan pengadukan agar reaksi tersebar merata dan gas yang terbentuk $\left(\mathrm{H}_{2} \mathrm{~S}\right.$, uap air dan senyawasenyawa yang memiliki titik didih dibawah $160^{\circ} \mathrm{C}$ ) dapat dinetralkan atau terbuang.

Tabel 1. Karakteristik BSR terdepolimerisasi Table 1. Characteristic of depolymerized BSR

\begin{tabular}{lcc}
\hline \multicolumn{1}{c}{\begin{tabular}{c}
\multicolumn{1}{c}{ Parameter mutu } \\
Quality parameter
\end{tabular}} & $\begin{array}{c}\text { BSR } \\
B S R\end{array}$ & $\begin{array}{c}\text { BSR terdepolimerisasi } \\
\text { Depolymerized BSR }\end{array}$ \\
\hline $\begin{array}{l}\text { Viskositas Mooney }\left(\mathrm{ML}(1+4) 100^{\circ} \mathrm{C}\right) \\
\text { Mooney viscosity }\left(M L(1+4) 100^{\circ} \mathrm{C}\right)\end{array}$ & 49,5 & 14,4 \\
$\begin{array}{l}\text { Plastisitas awal (Po) } \\
\text { Wallace plasticity (Po) }\end{array}$ & 26 & 12,5 \\
$\begin{array}{l}\text { Indeks ketahanan plastisitas (PRI) } \\
\text { Plasticity retention index (PRI) }\end{array}$ & 4 & 64 \\
\hline
\end{tabular}

Hasil pengujian (Gambar 1) menunjukkan bahwa penambahan bahan pemodifikasi memperlama waktu pencampuran dan meningkatkan titik lembek aspal termodifikasi. Waktu pencampuran aspal termodifikasi meningkat dua kali lipat dibanding aspal. Peningkatan waktu pencampuran ini disebabkan adanya bahan-bahan pemodifikasi yang ditambahkan sehingga diperlukan waktu lebih untuk menghomogenkannya.
Penambahan BSR terdepolimerisasi diharapkan dapat mempersingkat waktu pencampuran aspal dan karet alam. Hasil penelitian Prastanto (2014) menunjukkan bahwa penambahan 3\% (b/b) SIR 20 (tanpa didepolimerisasi) memerlukan waktu pencampuran selama 660 menit, sedangkan penambahan BSR terdepolimerisasi dan $2,4,6 \%$ (b/b) belerang pada aspal memerlukan waktu pencampuran selama 397-551 menit. Hal ini menunjukkan bahwa penambahan BSR terdepolimerisasi

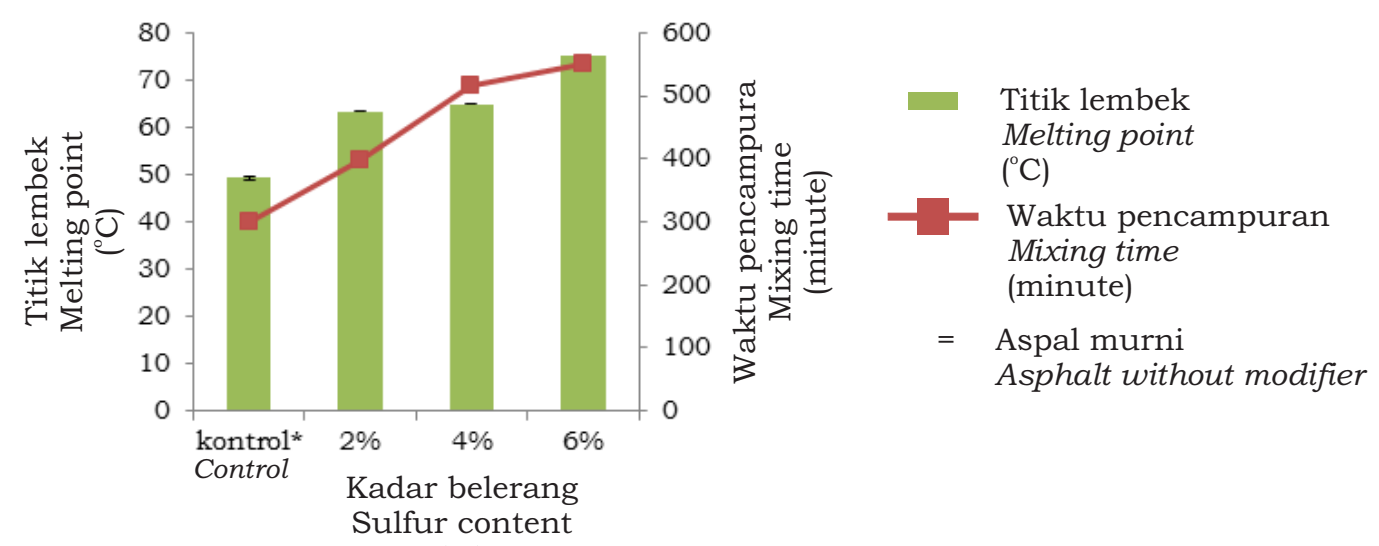
$(\%)$

Gambar 1. Pengaruh kadar belerang terhadap titik lembek dan waktu pencampuran aspal modifikasi

Figure 1. The influnce of sulfur content on mixing time and melting point of modified asphalt 
mempersingkat waktu pencampuran aspal dan karet alam.

Namun, waktu pencampuran ini masih lebih lama jika dibandingkan dengan aspal termodifikasi $7 \%$ SIR 20 terdepolimerisasi (hasil mastikasi selama 24 menit) yang memerlukan waktu pencampuran hanya selama 67 menit (Prastanto, 2014). Hasil ini menunjukkan bahwa penambahan belerang mempengaruhi waktu pencampuran aspal termodifikasi yang dihasilkan. Selain itu, reaktifitas yang tinggi selama proses pencampuran menyebabkan waktu pencampuran aspal termodifikasi belerang lebih tinggi dibandingkan resin.

Aspal termodifikasi memiliki titik lembek lebih tinggi dibandingkan aspal. Titik lembek aspal termodifikasi meningkat seiring dengan kadar belerang yang ditambahkan pada aspal termodifikasi. Hasil penelitian Chen dan Huang (2007) juga menunjukkan pola yang sama, bahwa penambahan persentase belerang pada aspal termodifikasi polimer (SBS) meningkatkan titik lembek aspal.

Titik lembek optimum dicapai dari pencampuran aspal dengan BSR terdepolimerisasi dan $6 \%(\mathrm{~b} / \mathrm{b})$ belerang sebesar $75^{\circ} \mathrm{C}$. Penambahan belerang menyebabkan meningkatnya ikatan silang antara aspal dengan bahan pemodifikasi, sehingga menyebabkan titik lembek aspal meningkat. Estrada et al (2010) menyatakan bahwa penambahan sedikit belerang pada aspal polimer (Styrene-Butadiene dan Styrene-Butadiene-Styrene) meningkatkan kompatibilitas polimer dengan aspal melalui pembentukan rantai ikatan silang, sehingga karakteristik thermomechanical aspal meningkat. Titik lembek aspal polimer sesuai SNI 6749:2008 harus memiliki nilai minimal $56^{\circ} \mathrm{C}$. Hal ini menunjukkan bahwa aspal termodifikasi BSR terdepolimerisasi dan belerang memenuhi persyaratan.

Hasil uji statistika dengan tingkat kepercayaan 95\% dan $\alpha=0,05$ menunjukkan bahwa nilai siginifikan perlakuan penambahan kadar belerang yang berbeda terhadap titik lunak aspal termodifikasi lebih kecil dari $\alpha$. Maka perlakuan penambahan kadar belerang yang berbeda berpengaruh secara signifikan pada nilai titik lembek aspal. Selain itu, hasil uji lanjut Turkey menunjukkan bahwa interaksi antar kadar belerang berpengaruh signifikan terhadap titik lembek aspal termodifikasi.

\section{Karakteristik Aspal Termodifikasi BSR Terdepolimerisasi dan Resin}

Campuran resin dan BSR terdepolimerisasi menunjukkan reaktifitas yang lebih rendah dibandingkan aspal termodifikasi menggunakan belerang. Secara visual, penambahan bahan modifikasi memiliki keadaan yang identik dengan pencampuran aspal tanpa bahan modifikasi. Namun, waktu pencampuran aspal termodifikasi memiliki rentang waktu yang lebih lama dibandingkan aspal.

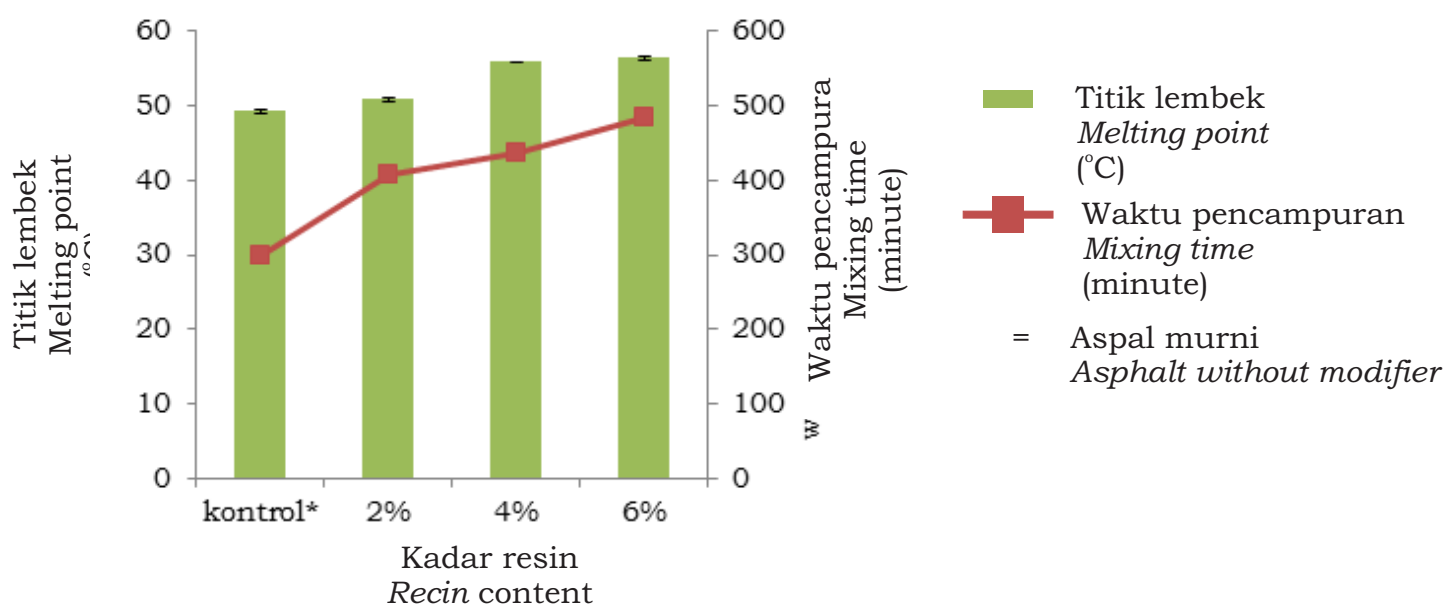

$(\%)$

Gambar 2. Pengaruh kadar resin terhadap titik lembek dan waktu pencampuran aspal modifikasi

Figure 2. The influnce of resin content on mixture time and melting point of modified asphalt 
Penambahan BSR terdepolimerisasi pada aspal dapat mempercepat waktu pencampuran aspal dengan bahan pemodifikasi jika dibandingkan dengan aspal yang dicampur karet alam tanpa depolimerisasi (Prastanto, 2014). Penambahan BSR terdepolimerisasi sebanyak $6 \%(\mathrm{~b} / \mathrm{b})$ hanya memerlukan waktu 407-485 menit, sedangkan penambahan 3\% (b/b) SIR 20 (tanpa depolimerisasi) memerlukan waktu pencampuran selama 660 menit. Hasil ini menunjukkan bahwa depolimerisasi pada karet alam mampu mempercepat waktu pencampuran aspal dan karet alam hingga 175 menit.

Waktu homogenasi campuran aspal, BSR terdepolimerisasi, dan resin memiliki waktu yang lebih cepat jika dibandingkan dengan aspal termodifikasi belerang. Aspal merupakan material heterogen yang terdiri dari asphalten (terdispersi) dan malten (pendispersi). Asphalten adalah hidrokarbon poliatom yang memiliki bobot molekul yang besar, sedangkan malten merupakan campuran koloid resin, lilin, kompon alifatik dan aromatik (Browarzik et al., 1999 dan Murgitch et al., 1996). Berdasarkan materi penyusun aspal tersebut, menunjukkan bahwa resin merupakan bagian dari aspal. Hal tersebut menyebabkan waktu pencampuran aspal termodifikasi resin lebih singkat dibandingkan dengan aspal termodifikasi belerang.

Titik lembek aspal termodifikasi BSR terdepolimerisasi dan belerang (Gambar 2) meningkat seiring dengan penambahan kadar resin. Bahan modifikasi dapat meningkatkan titik lembek aspal hingga $56,50^{\circ} \mathrm{C}$. Hasil penelitian Constatinides et al. (1986) dalam Becker et al. (2001) menerangkan bahwa parameter yang mungkin mempengaruhi kompatibilitas aspal-polimer adalah hubungan antara perbandingan asphalten/resin dan perbandingan rantai jenuh/aromatik. Ditambahkannya resin dalam aspal-polimer m e n y e b a b k n perbandingan asphalten/resin meningkat, sehingga menyebabkan kompatibilitas aspal-polimer meningkat dan meningkatkan titik lembek aspal. Selain itu, berdasarkan kepolarannya, resin (coumarone resin) dan aspal termasuk senyawa yang nonpolar (Martin-Martinez, 2009; Cong et al., 2011), sehingga kedua senyawa ini akan mudah bercampur.
Titik lembek optimum dicapai dari pencampuran aspal dengan BSR terdepolimerisasi dan 6\% resin sebesar $56,5^{\circ} \mathrm{C}$. Titik lembek optimum yang dihasilkan dari modifikasi aspal menggunakan BSR terdepolimerisasi dan resin lebih kecil dibandingkan aspal termodifikasi belerang, namun nilai tersebut masih memenuhi standar minimum yang dipersyaratkan SNI 6749:2008. Hal ini menunjukkan bahwa resin juga dapat digunakan sebagai bahan peningkat kompatibilitas antara aspal dengan polimer (khususnya karet alam).

Hasil uji statistika dengan tingkat kepercayaan $95 \%$ dan $\alpha=0,05$ menunjukkan bahwa nilai siginifikan perlakuan penambahan kadar resin yang berbeda terhadap titik lembek aspal termodifikasi lebih kecil dari $\alpha$. Maka perlakuan penambahan kadar belerang yang berbeda, berpengaruh secara signifikan pada nilai titik lembek aspal. Hasil uji lanjut Turkey menunjukkan bahwa interaksi antar kadar resin 2\% dan 6\% tidak berpengaruh signifikan terhadap titik lembek aspal termodifikasi.

\section{KESIMPULAN DAN SARAN}

Depolimerisasi BSR dapat menurunkan viskositas Mooney BSR sehingga mempersingkat proses pencampurannya dengan aspal. Peningkatan kompatibilitas aspal dan karet alam menggunakan belerang dan resin menunjukkan bahwa peningkatan kadar belerang dan resin semakin meningkatkan pula kompatibilitas aspal dengan BSR terdepolimerisasi, yang ditunjukkan dengan meningkatnya titik lembek aspal termodifikasi yang dihasilkan. Hasil uji statistika menunjukkan bahwa perlakuan penambahan kadar belerang yang berbeda terhadap titik lembek aspal berpengaruh signifikan, sedangkan penambahan kadar resin yang berbeda terhadap titik lembek aspal tidak beperngaruh signifikan. Karakteristik aspal termodifikasi BSR terdepolimerisasi dan belerang memerlukan waktu pencampuran yang lebih lama dan mampu meningkatkan titik lembek aspal yang lebih tinggi dibandingkan aspal termodifikasi BSR terdepolimerisasi dan resin. Komposisi aspal termodifikasi terbaik dihasilkan dari penambahan $6 \%(\mathrm{~b} / \mathrm{b}) \mathrm{BSR}$ terdepolimerisasi dan $6 \%(\mathrm{~b} / \mathrm{b})$ belerang, 
dengan nilai titik lembek yang dicapai sebesar $75^{\circ} \mathrm{C}$. Hasil penelitian ini diharapkan menjadi informasi yang berguna untuk pembuatan aditif aspal dengan menggunakan bahan yang murah yaitu BSR.

\section{DAFTAR PUSTAKA}

Becker, Y., M. P. Méndez., and Y. Rodríguez. 2001. Polymer Modified Asphalt. Vision tecnologica 9 (1): 39-50

Becker, Y., A. J. Müller., and Y. Rodríguez. 2003. Use of Rheological Compatibility Criteria to Study SBS Modified Asphalts. Journal of Applied Polymer Science 90: 1772-1782

Browarzik, D., H. Laux, and I. Rahimian. 1999. Asphaltene Flocculation in Crude Oil system. Fluid Phase Equilibria 154(2): 285-300

Chen J. S. and C. C. Huang. 2007. Fundamental Characterization of SBSModified Asphalt Mixed with sulfur. Journal of Applied Polymer Science 103(5): 2817-2825

Cifriadi, A., A. Ramadhan., dan H. Prastanto. 2012. Pencepat Waktu Pencampuran Aspal dan Karet Menggunakan Lindi Hitam untuk Pembuatan Aspal Modifikasi. Prosiding Konfrensi Nasional Karet. Yogyakarta, 19-20 September. Pusat Penelitian Karet.: 319-399.

Cong, P., C. Shanfa, Y. Jianying., and C. Huaxin. 2011. Compatibility and Mechanical Properties of Epoxy Resin Modified Asphalt Binders. International Journal of Pavement Research and Technology 4 (2): 118123

Cowd, M. A. 1991. Kimia Polimer (terjemahan). John Murray Ltd, London
Estrada, A. M., A. E. Cha'vez-Castellanos., M. Herrera-Alonso., and R. Herrera$\mathrm{Na}$ jera. 2010. Comparative Study of the Effect of Sulfur on the Morphology and Rheological Properties of SB- and SBS-Modified Asphalt. Journal of Applied Polymer Science 115: 3409-3422

Giavarini C., P. Defilippis., M. L. Santarelli., and M. Scarsella. 1996. Production of Stable Polypropylene-Modified Bitumens. Fuel 75(6): 681-686.

Kök, B. V. and H. Çolak. 2011. Laboratory Comparison of the Crumb-Rubber and SBS Modified Bitumen and Hot Mix Asphalt. Construction and Building Materials 25: 3204-3212

Murgich, J., J. Rodriguez., and M. Y. Aray. 1996. Molecular Recognition and Molecular Mechanics of Micheless of Some Models Asphaltens and resin. Energy \& Fuels 10(1): 68-76

Martin-Martinez, J. M. 2009. Rubber-Based Pressure-Sensitive Additive. In Benedek and Fenstain (Ed.). Technology of Pressure-Sensitive Adhesives and Product.,CRC Press, United states of America, : 2-20

Polacco, G., S. Berlincioni., D. Biondi., J. Stastna., and L. Zanzotto. 2005. Asphalt Modification with Different Polyethylene-based Polymers. European Polymer Journal 41: 28312844

Prastanto, H. 2014. Depolimerisasi Karet Alam Secara Mekanis sebagai Bahan Aditif Aspal. Jurnal Penelitian Karet 32 (1): 81-87

Refrizon. 2003. Viskositas Mooney Karet Alam. Skripsi. Jurusan Fisika, Fakultas Matematika dan Ilmu Pengetahuan Alam. Universitas Sumatera Utara, Medan 
Sun, D., F. Ye., F. Z. Shi., and W. Lu. 2006. Storage Stability of SBS-Modified Road Asphalt: Preparation, Morphology and Rheological Properties. Petroleum Science and Technology. 24(9): 10671077

Tuntiworawit, N., C. Phromsorn., and D. Lavansiri. 2005. The Modification of Asphalt with Natural Rubber Latex. Proceedings of The Eastern Asia Society for Transportation Studies. Bangkok, 21-24 September. Eastern Asia Society for Transportation Studies.: 679-694
Zhang, F. and J. Yu. 2009. The Resarch for Asphalt Modified with Phosphorus Trichloride/SBS. International Polymer Processing 24(2): 148-156

Xiang, L., J. Cheng., and G. Que. 2009. Microstructure and Performance of Crumb Rubber Modified Asphalt. Construction and Building Materials 23: 3586-3590 